\title{
Improving productivity of a financial firm: business model evolution in the Caribbean
}

\author{
David W. Parker \\ Business School, University of Queensland, Brisbane, Australia, and \\ William W. Lawrence \\ Mona School of Business and Management, University of the West Indies, \\ Kingston, Jamaica
}

\begin{abstract}
Purpose - This study explores the role of business model as a state variable during transformation of a financial institution to become a multinational enterprise. Prior studies of the Uppsala model overlooked business model evolution for cross-border productivity and performance.

Design/methodology/approach - The research design employs the resource-based view for an in-depth case study of JMMB, a family-managed Jamaica-based financial firm, using data from primary and secondary sources, covering the period 1992 to 2014.

Findings - JMMB's business model was the channel through which resources and capabilities gave rise to an innovative product for successful positioning in an international network. This was augmented by strong family orientation toward customer service, a distinctive asset that shaped the nature and trajectory of the business model. Cross-border alliancing and risk management were crucial dynamic capabilities for replicating the business model in foreign markets.

Research limitations/implications - While the observations are not generalizable to other firms, they indicate that a business model is a key unit of analysis for understanding how the firm makes the transition to become a multinational enterprise.

Practical implications - Financial institutions may internationalize in a small island, developing stages through a strategy of focused product differentiation based on disruptive innovation with cross-border partnerships for ease of market entry and experiential learning.

Social implications - The research has identified opportunities for effective and efficient work methods in pursuit of productivity gains.

Originality/value - The study is the first to illustrate business model as a state variable in the Uppsala model of multinational enterprise evolution for a financial firm.
\end{abstract}

Keywords Business model, Uppsala model, Internationalization, Caribbean, Financial case

Paper type Research paper

\section{Introduction}

Financial institutions often pursue market expansion in more than one country in an effort to improve productivity and financial performance by building economies of scale (Bouslama and Herve, 2018; Engwall and Hadjikhani, 2014; Grant and Venzin, 2009). The assets of these institutions are fungible and should be readily interchanged, in whole or part, with goods and services within and across country borders. However, internationalization is more challenging for financial institutions because of higher entry barriers by governmental regulation to protect domestic financial systems in critical areas such as deposits, loans, investments, currency exchange and payments.

While the literature describes several approaches for firm internationalization, researchers often use the Uppsala model, introduced by Johansson and Vahlne (1977), when evaluating strategic intent of financial institutions. The Uppsala model proposes that multinational enterprise (MNE) evolution occurs due to dynamic interplay of some change and state variables (Isaksson et al., 2015; Vahlne and Ivarsson, 2014; Vahlne and Johanson, 2013; Vahlne and Johanson, 2020). Change variables comprise decisions that commit the firm

Business
model
evolution for
productivity

Received 16 January 2019

Revised 9 January 2020 Accepted 16 February 2020 
IJPPM

70,2

to a certain strategy and value chain and include the processes of learning, creating and trust building. State variables describe the firm's resources, knowledge, capabilities and network position at a point in time.

In the Uppsala model, resources and dynamic capabilities give rise to MNE network position measured as the extent of profitability and globalness (Vahlne and Johanson, 2013). Firms display dynamic capabilities when they purposefully create, extend or modify tangible and intangible assets for competitive advantage (Helfat and Peteraf, 2015). However, literature is unclear about how resources and dynamic capabilities bring about the MNE network position in terms of productivity and financial performance. This gap needs closure to improve strategic decision-making particularly in the case of financial institutions where failure to intermediate effectively, in the transfer of funds from owners to consumers, can derail economic growth (Levine, 2018; Seven and Yetkiner, 2016).

The internationalization of Spain-based Banco Santander is a frequently cited case of financial firm internationalization, and this occurred through a business model focused on core values (Parada et al., 2009). Business model is the logic or architecture to create and deliver value for customers, entice customers to pay for value and convert those payments to profit (Zott and Amit, 2013; Wirtz et al., 2016). Firms use resources and dynamic capabilities to develop business models for competitive advantage (Teece, 2018; Augier and Teece, 2007). Thereafter, organizational processes embed the firm's strategy and business model into daily work routines (Teece, 2014). However, the Uppsala model of MNE evolution does not mention business model as a state variable (Vahlne and Johanson, 2019). According to Teece (2010, p. 172) "Whenever a business enterprise [including a financial institution] is established it either explicitly or implicitly employs a particular business model."

Drawing extensively from an in-depth case study of JMMB, a publicly traded financial firm located in the Caribbean, we adopt a parsimonious view to evaluate business model development, evolution, productivity and financial performance. Countries restrict the entry of foreign financial firms to protect their fiduciary and monetary policies against forces that can disrupt a domestic economy especially in a small island developing state (Hindley, 2001). Studies pertaining to how financial firms internationalize are needed urgently for information to overcome this challenge (Bouslama and Herve, 2018). Chronological strategic events allowed us to uncover JMMB's internationalization path and changes in performance (Marshall and Rossman, 2014).

JMMB demonstrates an interesting context for this study due to its imperative to internationalize from a small island developing state (Ogawa et al., 2013). Therefore, we explored the answer to the following research question: how does a financial firm evolve its business model when transitioning, by way of the Uppsala model, to become a successful multinational enterprise in small island developing states? Consistent with the resourcebased view, JMMB adopted the classic strategy of leveraging resources and dynamic capabilities to build and extend its business model for competitive advantage and improved market positioning (Teece, 2018; Grant, 1991). This revelation is an original contribution to international business literature and important because of the high prevalence of studies on the Uppsala model. Our case study provides evidence to further develop theoretical arguments about the internationalization process. The findings extend literature on the Uppsala model to illustrate the role of business model in the process of MNE evolution by a financial institution.

In the next section, we develop the conceptual framework from a review of theory and the concepts and process of the Uppsala model with evidence from Banco Santander (Parada et al., 2009). Then we describe the methodology of our research followed by analysis of the internationalization path of JMMB. The article concludes with summary of the findings, contribution to theory development, limitations of the study, opportunities for future research and implications for managerial practice. 


\section{Theoretical background}

\subsection{The Uppsala model of MNE evolution}

The literature underscores three determinants of financial firm internationalization as follows: comparative advantage in capital cost and managerial expertise, internalization to protect business assets and the eclectic paradigm that considers location (Tschoegl, 1987). Based on earlier work by Penrose (1959) and Cyert and March (1963); Johanson and Vahlne (1977) proposed a behavioral and risk-minimizing model of internationalization developed at Uppsala University from studies of Swedish firms. They observed that this process begins first, in nearby (or culturally similar) markets, and then the firm gradually enters other markets that are further away in psychic distance. Banco Santander began internationalization by leveraging its interest rate advantage in Latin America, due to this region's similar language, cultural affinity with Spain and low bank penetration, with subsequent business model replication in European countries closer to its home market (Parada et al., 2009).

MNEs learn from experience and use this knowledge to make subsequent decisions about the level of commitment and activities. Banco Santander made successful bank acquisitions for market entry in Latin America and later used this experience to penetration markets in Europe. Experiential learning helps organizations to recognize and develop opportunities and build stakeholder commitment in an environment of trust to overcome liabilities from newness and foreignness. Learning and commitment building take time but are necessary to change or extend the business model (Teece, 2014).

The original Uppsala model was further developed to recognize foreign networks of relationships for building trust and commitment to overcome the liability of outsidership (Johanson and Vahlne, 2009). Firms develop a set of close and enduring relationships with critical suppliers, customers and other constituents that become networks for opportunity recognition, growth and profitability. Banco Santander decentralized front offices giving local managers wide latitude, with headquarters support, to use their contacts to attract customers and develop commercial relationships. The nature of these relationships depend on psychological characteristics of managers and arise from social exchange processes that build trust and then reciprocal commitment between the firm and connected parties (Vahlne and Johanson, 2019). Firms participate effectively in networks of relationships thereby creating new knowledge through exchanges in critical areas such as resources and capabilities. New knowledge is the basis for business model extension and transformation (Teece, 2014).

Some scholars challenged the perspectives of the Uppsala model and argued that the notion that firms begin internationalization in nearby markets overlook e-commerce and born-global firms (Oviatt and McDougall, 1994; Cattani and Tschoegl, 2002; Forgren and Hagstrom, 2007; Schueffel et al., 2014; Coviello et al., 2017). However, financial groups from emerging economies prefer to internationalize incrementally in their respective home regions (Outreville, 2013). Countries located in the same geographic area often have similar cultural characteristics, and this facilitates business model replication (Teece, 2014).

The Uppsala model focuses on internationalization based on psychic distance and gradualism. MNEs can more easily build the relationships necessary for spotting and exploiting opportunities when there is minimal perceived difference in conditions or psychic distance between home and foreign country (Johanson and Vahlne, 2009). International evolution occurs gradually as the MNE gains knowledge, in an environment of uncertainty, while keeping commitment and risk-taking at acceptable levels. Banco Santander's business model focused squarely on retail banking in underbanked countries with tight controls over credit risk, human resource development and information and communications technology. The MNE builds dynamic capabilities to extend or reconfigure the firm's resources for penetrating target markets (Vahlne and Johansson, 2013). 
IJPPM

70,2

\subsection{Resources and dynamic capabilities}

Scholarly research on dynamic capabilities has roots in the resource-based view of the firm (Penrose, 1959; Wernerfelt, 1984). Resources that are valuable, rare, inimitable and nonsubstitutable tangible or intangible assets, called VRIN resources, can be the foundation for achieving competitive advantage (Barney, 1991). The firm formulates strategy and earns profits by using these distinctive resources and capabilities in specific activities (Helfat and Peteraf, 2003; Winter, 2003; Grant, 1991). Banco Santander leveraged its large capital base and profits to pay higher interest on saving accounts compared to all other banks in Spain.

Firms may possess dynamic capabilities that purposefully reconfigure the way resources are combined to mitigate threats or seize opportunities (Eisenhardt and Martin, 2000). Experiential learning is the main method for developing dynamic capabilities such as knowhow, relationships and reputation (Helfat and Peteraf, 2015). Banco Santander developed progressively superior information systems and human resource policies to assess credit risk quickly and minimize arrears on loan repayment.

The Uppsala model recognizes three types of dynamic capabilities arising from organizational learning processes (Vahlne and Johanson, 2013). The first is opportunity sensing by market probing, listening to customers and scanning the ecosystem. Banco Santander collected information about consumer spending and income patterns in order to tailor retail products to the needs of customers. The second is internationalizing by seizing opportunity to secure and orchestrate the assets, incentives and relationships necessary for developing foreign markets. Banco Santander targeted deregulated markets in underserved niche segments open to foreign institutions. The third dynamic capability is networking by interacting and exchanging value with constituents to build, coordinate and sustain the business and relationships. Banco Santander forged a long-term strategic alliance with Royal Bank of Scotland to understand the United Kingdom market and identify target firms for entry.

\subsection{Network position}

The network position pertains to the nature of the MNE's market presence (Vahlne and Johanson, 2013; Vahlne and Ivarsson, 2014). The performance variables associated with network position include the degree of geographical dispersion, extent of integration between subsidiaries and parent firm, profitability and size. Over the first 20 years of internationalization, Banco Santander outperformed rivals in respect of income, international reach, asset growth, cost-to-income-ratio and profit growth. In the MNE network, the business model is the channel for effective product and service delivery as well as communication and coordination between the parent and subsidiaries (Forgren, 2016; Parada et al., 2009). Indeed, Banco Santander obtained valuable information for innovation from effective communication and coordination.

\subsection{Business model for MNE financial intermediation}

In the Uppsala model, dynamic capabilities are deployed to give rise to the MNE network position. There is no mention of business model. However, dynamic capabilities will yield superior firm performance only if deployed through an appropriate business model (Teece, 2018 and 2014). This implies that the Uppsala model needs clarification to include business model as a state variable receiving and deploying resources and capabilities to achieve the MNE network position. The business model specifies the way opportunities are developed, how internationalization occurs and the partners, customers and products (Teece, 2018; Chesbrough and Rosenbloom, 2002; Osterwalder and Pigneur, 2010; Rask, 2014).

Business models for financial intermediation involve sourcing capital from shareholders, depositors and investors to provide loans, securities brokerage, pension funds and insurance 
services. Financial institutions receive interest income, fees and insurance premiums from clients and pay out interest to depositors, dividends to shareholders, pension settlements, reinsurance fees and insurance claims. Financial intermediation takes place within a regulated system that includes banking and nonbanking institutions, money and capital markets, instruments of various maturities and a multiplicity of asset/fund-based and feebased services. Business model deployment across borders occurs by adapting to local conditions, aggregating resources for cost reduction or arbitrage to exploit differences between markets.

Theoretically grounded in the resource-based view, Table 1 shows our framework for evolution of financial institutions to become MNE. This is a three-phase process as follows: leadership in the home market, creating foreign market options and foreign market entry and integration. In the first phase, the institution identifies unmet demand and then organizes resources and capabilities for competitive advantage and market leadership (Grant, 1991). Financial institutions must navigate regulatory requirements, such as minimum capital reserves. The reach of the institution is not yet international, and growth arises from deploying a business model in the home market only.

In the second phase, the institution increases capital in preparation for international expansion and undertakes a search process to identify and learn about potential foreign markets for entry. Issues such as regulatory requirements, risk and taxation are of central importance. This involves data collection and analysis, multimodal communications and building critical relationships to overcome the newness, foreignness and outsidership

\begin{tabular}{ll}
$\begin{array}{l}\text { State variables in } \\
\text { Uppsala model } \\
\text { (resource-based } \\
\text { view) }\end{array}$ & $\begin{array}{l}\text { Phase 1 } \\
\text { Leading at home }\end{array}$ \\
\hline Resources & $\begin{array}{l}\text { Research for granular } \\
\text { information on business } \\
\text { opportunity }\end{array}$ \\
& $\begin{array}{l}\text { Financial capital and } \\
\text { regulatory approvals } \\
\text { Talent, work procedures } \\
\text { and physical } \\
\text { infrastructure }\end{array}$ \\
& $\begin{array}{l}\text { Product and service } \\
\text { innovation to satisfy the } \\
\text { market opportunity }\end{array}$
\end{tabular}

Business model Value proposition and value chain for differentiated financial intermediation

Network position

Domestic market penetration to increase client base, revenues, profits and assets
Phase 2

Creating foreign options

Phase 3

Financial capital and talent for cross-border investments and management

Foreign market entry

Deployment of assets, work practices, systems and structures to embrace new opportunity in target market

Environmental scanning to sense opportunities in nearby compatible markets

Experiential learning to penetrate markets further away in psychic distance Negotiated channels and regulatory approvals for market entry

Firm readiness for international business

\begin{abstract}
Alliancing to convey and deliver the value proposition to potential stakeholders in the target market
\end{abstract}
Deployment of cross-border value chain. Centralized IT and risk management at parent company. Marketing and sales decentralized to foreign market. Value-based pricing Increased market scope, revenues, profits, assets and customers

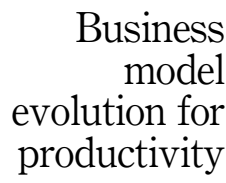

281

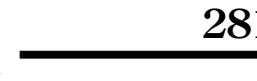


IJPPM

70,2

282

associated with internationalization. Attractive foreign markets have short psychic distance from home, latent client demand, low barriers to market entry and good potential for profitable growth. The firm prepares the work plan and team for business model extension and replication.

During the third phase, the institution makes decisions that commit resources to change geographical footprint, value chain and focal network. This new MNE learns how to coordinate the internal and external activities across borders. Dynamic capabilities are leveraged with other business model elements to move the institution into the foreign market and develop the desired network position.

The fundamental proposition and contribution of our conceptual framework is inclusion of business model as a state variable within the Uppsala model. This resource-based internal feature is the receptacle for MNE resources and dynamic capabilities and also the channel through which these are leveraged to achieve the network position. Three French cases described by Bouslama and Herve (2018) support the framework. The concepts and relationships have flexibility to provide guidance for various financial institutions and situations while addressing practical managerial challenges. The business model for financial firms to penetrate foreign markets provides differentiated products that leverage competitive advantage, responsive service delivery and value-based pricing. The framework is useful for theoretical and applied analyses of the MNE internationalization process and guides our process for answering the research question.

\section{Methodology}

\subsection{Research setting}

The Caribbean includes the islands and surrounding coasts of the Caribbean Sea (Caribbean Centre for Money and Finance, 2013), with economic growth declining in the region over the last 20 years, with high levels of poverty, underemployment and public sector debt (International Monetary Fund, 2013). These economies rely mainly on commodity exports, tourism and remittances from nationals residing outside the region. The Caribbean presents an opportunity to study business model evolution during financial firm internationalization within the context of small island developing states that have nontradable currencies, underdeveloped capital markets and higher interest rates than developed countries. Moreover, the multicultural nature of the region facilitates observation of gradualism and psychic distance which are core features of the Uppsala model.

The Caribbean financial services sector is large, relative to the size of regional economies in terms of Gross Domestic Product (GDP) and comprises mainly banks, insurance companies, credit unions, building societies, remittance firms, micro-finance agencies and securities dealers (Ogawa et al., 2013). Central banks play a central role with responsibility for financial system stability by regulating the activities of deposit-taking and nondeposittaking institutions. They also promote the development of capital markets and support the clearing and settlement mechanisms for funds transfer in a range of financial transactions.

The operations of financial institutions have substantial impact on the economies of the region, and commercial banks represent the largest category of assets (Holden and Howell, 2009). Foreign banks account for over $60 \%$ of total bank assets, and they are mostly regional subsidiaries of Canadian-based institutions. Financial institutions typically adopt product diversification as a strategy for coping with market saturation by offering a range of banking, insurance and wealth management services.

In the Caribbean financial system, license approvals are rare and expensive. The unbanked and underbanked market segment is estimated to be over $40 \%$ of the population. Most products and services are mature and undifferentiated in weak small island developing states. Clients are price-sensitive. Capital markets are underdeveloped. The securities market, the 
major domain of JMMB, comprises new and secondary issues done through either an organized stock exchange or over-the-counter market, such the Government Securities Market.

\subsection{Research design}

The design is a single in-depth case study based on social constructionist epistemology (Easterby-Smith et al., 2008; Burr, 1995). This method was also adopted by Bouslama and Herve (2018) and Parada et al. (2009) to study financial institutions. Case studies provide holistic accounts of the nuances of phenomena to reveal organizational concepts and dynamics hidden from other forms of empirical inquiry and answer what or how questions from observation of causal mechanisms (Cresswell, 2008; Gerring, 2004). A single case study gives a more granular understanding of specific phenomenon compared to multiple case studies. There is also rich description of events and linkages that cannot be achieved economically with large samples.

The case method is susceptible to researcher bias, and the findings are not generalizable to the population of interest (Yin, 2009). However, the intent of this study is not generalization but instead to illuminate mechanisms and important variables, processes and interactions during financial firm internationalization (Ahmad, 2012; Lee et al., 2014; Isaac and Michael, 1990, p. 48). In contrast to relativist inquiries, such as those described by Eisenhardt (1989), social constructionist studies do not generate theory from pattern recognition but instead make direct observations within a single organization with retrospective accounts of what happened (Stake, 2006; Langley, 1999).

The pioneers of the Uppsala model called for case studies to understand the strategic considerations and contextual aspects of the Uppsala model (Vahlne and Johanson, 2013; Vahlne et al., 2011). Moreover, the literature contains several case studies of firm internationalizations, including financial services (Parada et al., 2009; Sun, 2009; Ahmad, 2012; Boojihawon and Acholono, 2013; Lee et al., 2014; Amaratunga and Baldry, 2001). However, we argue that prior studies of the Uppsala model give insufficient attention to business model evolution. Indeed, Forsgren (2016) underscored the need for studies to clarify the relationship between business models and firm internationalization.

Our case study of JMMB, currently the largest securities dealer in the Caribbean, provides unique insight into how a small securities brokerage firm achieved international expansion in a region dominated by large foreign-based banks (Ogawa et al., 2013). This inquiry provides detailed description of the use of resources and dynamic capabilities to extend a business model across national borders (Eisenhardt, 1989; Eastersby-Smith et al., 2008). Much of the literature on financial firm internationalization focus on banking and insurance (Eppink and Van Rhijn, 1988; Hellman, 1996; Ahmad, 2012). However, our idiographic study of JMMB adds an example of a securities brokerage firm to the body of knowledge.

Validity and reliability are critical issues in case research (Gibbert et al., 2008). Our study paid attention to the following three criteria for validity in the constructionist research design: (1) authenticity by demonstrating deep understanding of relevant activities by JMMB, (2) plausibility by linking observations to the conceptual framework and (3) criticality by questioning assumptions to find fresh insights. To enhance construct validity and minimize researcher bias, we maintained a chain of verifiable evidence and triangulated responses from interviews with data from secondary sources to capture perceptions accurately. The study gained internal validity by providing plausible logical arguments and comparing observed patterns, with predictions from the Uppsala model.

\subsection{Data collection and analysis}

The intent of this research is to exemplify the business model as a concept for financial firm internationalization rather than external validity that generalizes data to a population. The

\section{Business model evolution for productivity}

283 
IJPPM

70,2

analysis generated insights for theory development by comparing case observations to expectations from the Uppsala model. This research-controlled relieson documenting the procedures, including interview protocols. We defined the concepts and translated the responses from interviews and archived data into the theoretical language used by Vahlne and Johanson (2013) and Vahlne and Ivarsson (2014) for the Uppsala model.

Guided by the conceptual framework, the data spanned the period 1992 to 2014 to capture chronologically the antecedents and dynamics of JMMB's internationalization path and process. Similar to the approach used by Bouslama and Herve (2018) and Ahmad (2012), we conducted detailed analysis of over 120 documents to obtain information on JMMB's strategic path, changes in product mix and geographical footprint, cross-border alliances, productivity and financial performance. We also conducted 90 min individual interviews with two senior managers and two Board Directors who were involved directly with JMMB's transition to MNE. These interviews provided critical insights into managerial cognitions, decisions, obstacles encountered and actions taken.

Data analysis was done in three sequential and overlapping periods or sections commensurate with the steps shown in the conceptual framework. The first period of analysis spanned between 1992 and 2000 during which JMMB moves from start-up, to become the leading money market brokerage firm in Jamaica. The second period ran from 1998 to 2007 during which JMMB created options for international expansion in the Caribbean. The final period spanned between 2002 and 2014 during which JMMB penetrated foreign markets and integrated the subsidiaries into the operations of the group. These time periods are phases in the internationalization process and overlap to capture the multiple Caribbean markets penetrated by JMMB, as follows: Trinidad and Tobago, Barbados (from which JMMB later withdrew) and the Dominican Republic.

In respect of the state variables in the Uppsala model, we analyzed JMMB's resources by looking at how assets were acquired and deployed during each period (Peteraf, 1993). Tangible assets included financial capital, technology and equipment, human resources and physical infrastructure. Information about these assets were taken from audited financial statements, official annual reports and internal company documents such as employment records and assets released to the Financial Services Commission. We used the interviews to discern intangible assets including brand strength, employee know-how, business relationships and family values.

We analyzed dynamic capabilities by noting the actions taken to build employee knowhow, sense opportunities, mobilize resources, establish linkages and partnerships and penetrate markets (Teece, 2014). This information was obtained from the interviews, published research articles and official company releases to the media and the Jamaica Stock Exchange. We paid attention to human-related competences such as new product development, capacity to manage risk, customer service delivery and alliancing capability.

We discerned evolution of JMMB's business model by mapping changes in the elements specified by Osterwalder and Pigneur (2010). These include value proposition, value chain (partnerships, resources, activities, customer channels, customer relationships and customer segments), cost model and revenue model. Information was obtained from annual reports, published research articles, the interviews and internal company documents. The way dynamic capabilities interacted with VRIN resources, to extend the business model, was of particular interest. The network position was analyzed with respect to number of foreign countries, business segments, foreign assets, productivity and profitability.

The observations were compared with the elements of the conceptual framework to detect areas of agreement or departure. In instances, where observations differed from the framework, clarifications and explanations were sought by contacting the interview participants. Finally, the observations were compared to theoretical arguments from Vahlne and Johanson (2013) and Vahlne and Ivarsson (2014) to conclude the answer to the research question. 


\section{Case: JMMB's internationalization journey}

\subsection{Leading at home}

In the early 1990s, the Jamaican stock market declined, and high interest rates stimulated growth of the money market. The Government of Jamaica borrowed substantial sums from local financial institutions and paid high yields. Small investors were excluded from these transactions, and there was no secondary money market. Banks were unwilling to take the risks associated with serving this segment. An experienced banker, Joan Duncan, seized this commercial opportunity by establishing a family business called JMMB. She obtained the first Jamaican license to retail government debt securities, to individual and institutional investors, using repurchase agreements in a secondary money market.

JMMB negotiated financing from four local joint venture agreements for equity capital to purchase bond securities from the Government of Jamaica. This type of alliancing enables financial risk-sharing and was a crucial capability in JMMB's business model to penetrate foreign markets. Joint ventures also help to avoid the liabilities of newness, foreignness and outsidership warned by Vahlne and Johanson (2013).

Initially, JMMB had a small staff managed by Joan Duncan and her daughter, Donna. Other family members later joined the business, and the total workforce increased to 30 employees operating from a relatively small office in Kingston, the capital city. Joan used her experience in banking to coach her employees on how to manage risk and credit while providing good customer service. The Duncan family instituted client care and partnership agreements to infuse JMMB's procedures and practices with their family values of love, integrity, fun, togetherness and accepting responsibility. These relationship-oriented values were nontraditional in the Jamaican financial services sector, accustomed to detached transactions, and it became a VRIN resource for attracting clients in local and foreign markets.

JMMB developed privileged relationships in the financial sector and risk management know-how as other intangible assets for focused service differentiation in the small developing market. Low operating costs enabled the firm to give clients higher returns than those available from commercial banks. Employees were motivated by attractive compensation, performance incentives, childcare facilities, subsidized meals and staff fitness facilities. Offices had home-like atmosphere with cheerful and youthful staff dressed semi-casually delivering excellent service quality. Reception and meeting areas had living room décor in bright colors and were open and cozy. Refreshments were provided for clients. JMMB had an official statement called the "Vision of Love" that stated the following:

The atmosphere that JMMB is in the process of developing may be defined as an energy field where overlapping circles of creativity, passion, excitement, fun and laughter coexist in a dynamic process that ultimately leads to higher and higher levels of self-actualization; hence, the achievement of the organizational mission.

Rival institutions would have difficulty replicating JMMB's business model because of the idiosyncratic nature of JMMB's family values. Management held frequent meetings with clients and employees to get feedback on how to improve customer service and operating procedures. In a 1994 interview with the Financial Gleaner newspaper, Joan Duncan stated the following:

Every decision is not only about making money; it's about serving our clients, serving team members and about making money for our shareholders ... It has been sheer hard work and application which has helped me ... people come here because of what we offer, not because of who I know ... my greatest desire is not to make a lot of money for myself but to have a clean heart and a clean spirit.

JMMB's infrastructure network was similar to those local commercial banks with branch offices in major Jamaican towns, and clients could also conduct transactions using the 
IJPPM

70,2

internet, telephone or automated teller machines. Clients borrowed money at attractive interest rates using their investments as collateral. JMMB also provided financial advisory and stock brokerage services. JMMB published attractive interest rates weekly, wrote newspaper articles about the money market and held public forums to promote the benefits for small investors. The official company slogan was "nobody knows the money market better than we do. Full stop."

The path that JMMB took to establish a leading position in the home market is consistent with our conceptual framework derived from theory and literature. The institution identified a unique commercial opportunity, then leveraged resources and capabilities in a low costhigh value business model for focused service differentiation. Competition was initially absent because banks were averse to risk-taking on the secondary securities market. By 1998, after just six years of operation, JMMB had accumulated about 40,000 customers and achieved $38 \%$ return on average equity.

JMMB's successful entry into the financial services sector occurred by way of disruptive innovation (Johnson et al., 2008). Retailing of government debt securities to small investors created a new market segment and motivated customers to transfer their savings from low interest accounts at commercial banks to higher yield repurchase agreements at JMMB. Disruptive innovation in the financial services sector is typically associated with radical change driven by technology (Beck et al., 2016; DeYoung et al., 2007). In contrast, JMMB combined business know-how, in a strategy of focused service differentiation, with strategic alliancing and core family values functioning as a set of intangible assets to spur profitable growth.

Joan Duncan died in 1998 leaving her values imprinted in JMMB's culture. JMMB's website and every branch office carried her picture and detailed description of her life story and values. Family members continued to hold leadership positions at the top of the organization, and Donna Duncan was the CEO until 2005 when she handed the reins to her twin brother Keith Duncan. Donna remained with the company in a new post, called Group Executive Director - Culture and Leadership Development, to reinforce the Duncan family values in JMMB's strategy and operations. JMMB's first phase of development focused on building a strong and competitive business model to serve a niche segment of the market and laid the foundation for international expansion (Teece, 2014).

\subsection{Creating foreign options}

By the late 1990s, Jamaica's financial sector experienced liquidity crisis arising from earlier liberalization of trade and foreign controls. The government took control of distressed institutions, provided liquidity support and enacted stricter financial regulations. Interest rates declined and the spreads narrowed substantially. In addition, several commercial banks entered the secondary money market where JMMB was initially the only player.

These conditions motivated JMMB to search for options to replicate business model in foreign markets. JMMB was aware that international expansion involves major resource commitments, and the strategic choices would impact its performance (He and Wei, 2011). Management scanned the regional environment to identify potential markets and find financial institutions for partnerships. The search focused on countries within the Commonwealth Caribbean with language, cultural or trade arrangement compatible with Jamaica (low psychic distance). Other criteria for market selection included latent demand for securities brokerage, favorable spreads between long-term and short-term interest rates, favorable regulatory regime and political and economic stability (Figure 1).

The Republic of Trinidad and Tobago (Trinidad) became first choice because of short psychic distance. Both countries are English-speaking members of the Caribbean Common Market (CARICOM) and have similar social infrastructure and political and regulatory 


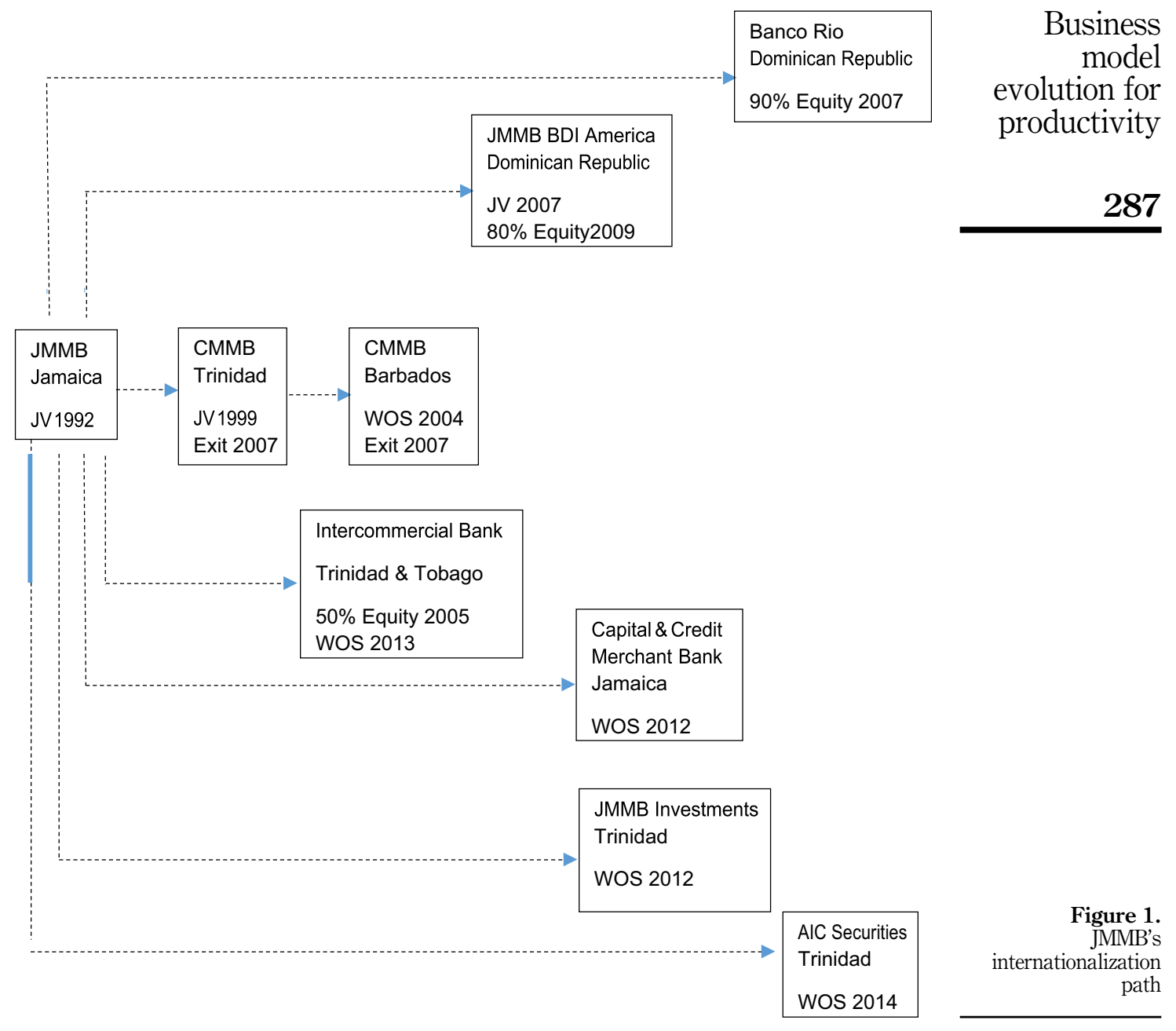

regimes. Trinidad is one of the strongest Caribbean economies in terms of GDP per capita. Furthermore, Jamaica enjoyed excellent diplomatic, social and trade relations with this oilbased country where the capital market was underserved (Ogawa et al., 2013).

Trinidad-based CL Financial emerged as JMMB's partner of choice. This global investment holding conglomerate was involved with insurance, banking, real estate, manufacturing, retailing, distribution, agriculture, energy and health services in over 35 countries, including most of the Caribbean. JMMB negotiated a joint venture agreement with CL Financial in 1999 to establish a securities brokerage firm called Caribbean Money Market Brokers (CMMB) in Trinidad and took a minority $45 \%$ ownership with responsibility to manage this entity. JMMB was hopeful that this alliance would be replicated in other countries across the Caribbean. This partnership was successful for the first seven years, with penetration of the Barbados market in 2004. However, in 2007, JMMB sold its shares to the joint venture partner to exit CMMB just one year before the corporate collapse of CL Financial. 
IJPPM

70,2

\section{8}

In 2007, JMMB negotiated a license to purchase and trade securities in the Dominican Republic, a Spanish-speaking Caribbean country and acquired a brokerage house in Santo Domingo, a major city. The CEO stated as follows:

Our successful launch of JMMB-BDI America in the Dominican Republic represents the entry point into the Central America free trade area. We will be targeting underserved markets to share the Jamaican experience in the areas of securities trading and risk management. Our plan is to start small in the markets and develop over time. By the end of 2010, we intend to be in two other territories. Explorations are being done in Costa Rica, Honduras and El Salvador, with indications that Costa Rica is likely to be one of the two.

These strategic moves to create options in foreign markets are in line with the prescriptions in our conceptual framework showing that the MNE will begin in nearby markets (Trinidad and Tobago) and gradually expand further away (Dominican Republic) in terms of psychic distance. Although JMMB had sufficient financial reserves for the CMMB joint venture, management was aware that more capital would be required for additional international expansion. The firm had an initial public offer (IPO) on the Jamaica Stock Exchange in 2002 which was oversubscribed, with many of JMMB clients participating.

The internationalization path of JMMB indicates that creation of options in foreign markets can take a long time and be nonmonotonic. The Uppsala model posits that learning and commitment occurs over time which explains why JMMB's investments in banking were made gradually from 2004 to 2012 . The financial firm needs to be patient with sufficient longterm capital to stay in the course. Subsequent to the IPO, JMMB tapped the Jamaica Stock Exchange periodically to obtain equity capital by way of shares. The evidence also suggests that partners in a strategic alliance must have similar vision and risk propensity to sustain the relationship. After exiting CMMB, JMMB later established its wholly owned subsidiary (WOS) securities brokerage firm in Trinidad in 2012 by leveraging its experience and network developed during joint venture.

\subsection{Foreign market entry and integration}

JMMB entered a joint venture with the following two financial firms in Trinidad to launch Caribbean Money Market Brokers Limited (CMMB): CL Financial Limited (10\% equity partner) and its subsidiary CLICO Investment Bank (45\%). This strategic move reduced liabilities of newness, foreignness and outsidership. The staff comprised mostly local personnel including the CEO. CMMB initiated the secondary market for fixed income securities including government treasury bills, bonds and commercial paper in the two major cities, Port of Spain and San Fernando. In 2003, CMMB established a securities company to trade equities as another joint venture between JMMB and CL Financial. According to Vahlne and Johanson (2013, p. 199) "while exchanging products, services and knowledge in the network relationships, new opportunities emerge."

In 2004, CMMB opened an associate company in Barbados aiming to take at least $10 \%$ of the island's fixed income market. This brokerage house also offered stocks and money markets funds. JMMB owned $50 \%$ of CMMB Barbados with $10 \%$ owned outright and $40 \%$ through its joint venture partner CMMB (Trinidad). CMMB Barbados had six employees and operated from rented space in Bridgetown, the capital city, with a capitalization of US\$5 m.

In 2007, JMMB sold its stake in CMMB to CL Financial citing the need to redeploy assets to expand its product range. Tensions among joint venture partners due to differences in risk tolerance and management style also motivated JMMB's exit. A foreign market can be unattractive or become unsuitable after MNE entry. However, in late 2012, JMMB opened its wholly owned securities brokerage firm called JMMB Investments Trinidad and Tobago. JMMB also diversified its business portfolio in Trinidad by acquiring AIC Securities, a firm engaged in wealth management services. 


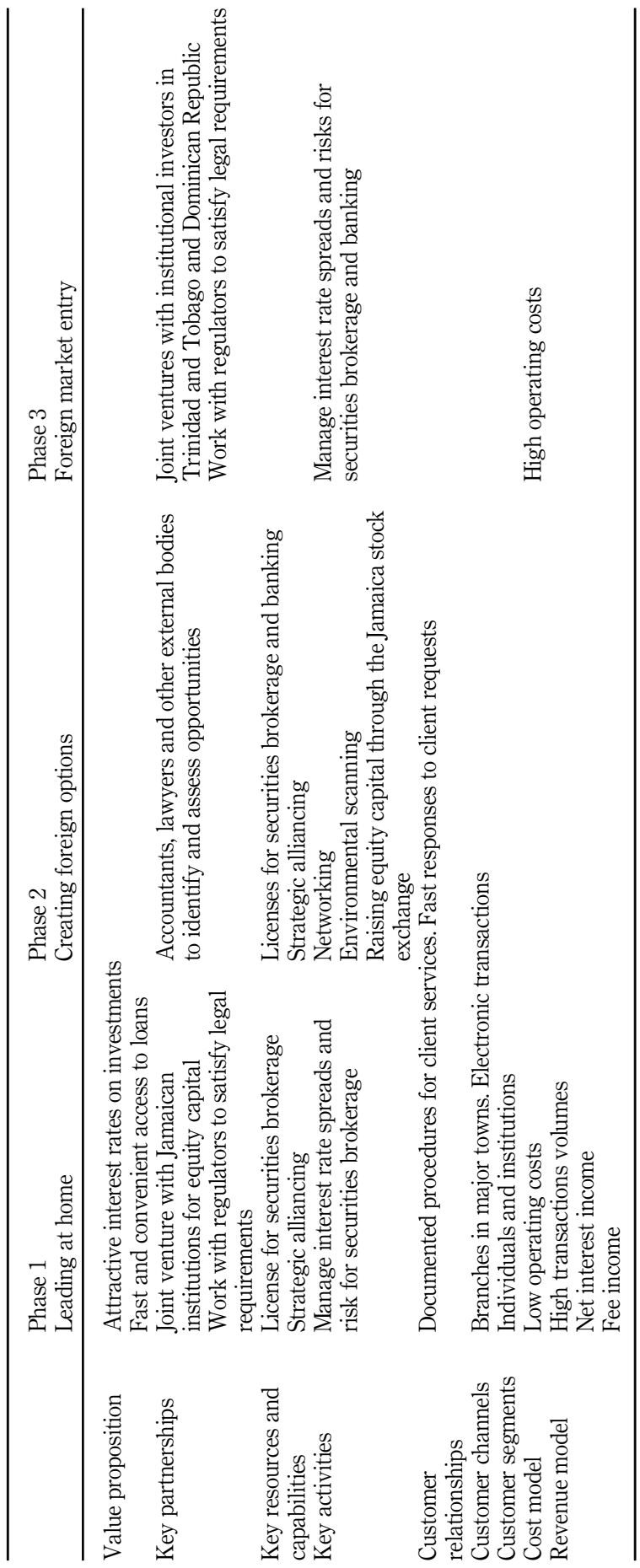

Business model evolution for productivity

289

Table 2.

JMMB's business model evolution to become MNE 
IJPPM

70,2

290

In 2007, the company launched its subsidiary JMMB BDI America, in the Dominican Republic. This was an equity partnership with Banco BDI and Corporacion de Credito America (CCA), to retail Government repurchase agreements. In 2009, JMMB acquired 80\% ownership of its joint venture partner, CCA for US $\$ 1.2$ million. In 2014, JMMB acquired $90 \%$ ownership of Banco Rio de Ahorro y Credita with plans to merge this entity with CCA to offer a broad range of savings and loan products. JMMB had planned to use its subsidiaries in the Dominican Republic to penetrate markets in Central America by year end 2010 but found that the interest rate and regulatory regimes were incompatible with its business model.

In 2004, JMMB purchased 50\% equity stake in Intercommercial Bank (IBL), a small commercial and merchant bank in Trinidad with two branches. This shift was a strategic move to continue diversification of JMMB's business model in light of new regulations in Jamaica that required a third party or trustee to take custody of the securities underlying retail repurchase agreements. This new regulation meant that JMMB could no longer generate revenues by trading repos to different customers using the same collateral. In June 2012, the company completed acquisition of the Capital and Credit Financial Group in Jamaica to offer merchant banking, remittance and unit trust products. In 2013, the company acquired the remaining stake for $100 \%$ ownership of IBL and further pursued its goal of being a fully integrated regional financial services company with securities dealing, stock brokering, foreign exchange trading, banking and insurance brokerage.

JMMB's organizational structure continued to evolve during internationalization as strategic decisions were made to change commitments or pursue new opportunities. In 2013, the Board approved transfer of the shares of all JMMB subsidiaries to a newly formed holding company called JMMB Group.

Table 3.

Changes in JMMB's network position during internationalization

\begin{tabular}{lcccc}
\hline Performance criteria & 1998 & 2002 & 2007 & 2014 \\
\hline Number of foreign countries & 0 & 1 & 2 & 2 \\
Number of business segments & 2 & 3 & 5 & 7 \\
Number of employees & 94 & 161 & 292 & 578 \\
Number of customers & 40,000 & 70,000 & 130,000 & 220,000 \\
Foreign assets \% total assets & 0 & $6 \%$ & $13 \%$ & $22 \%$ \\
Return on average equity & $38 \%$ & $42 \%$ & $15 \%$ & $17 \%$ \\
\hline
\end{tabular}

Figure 2.

Financial performance of the JMMB group

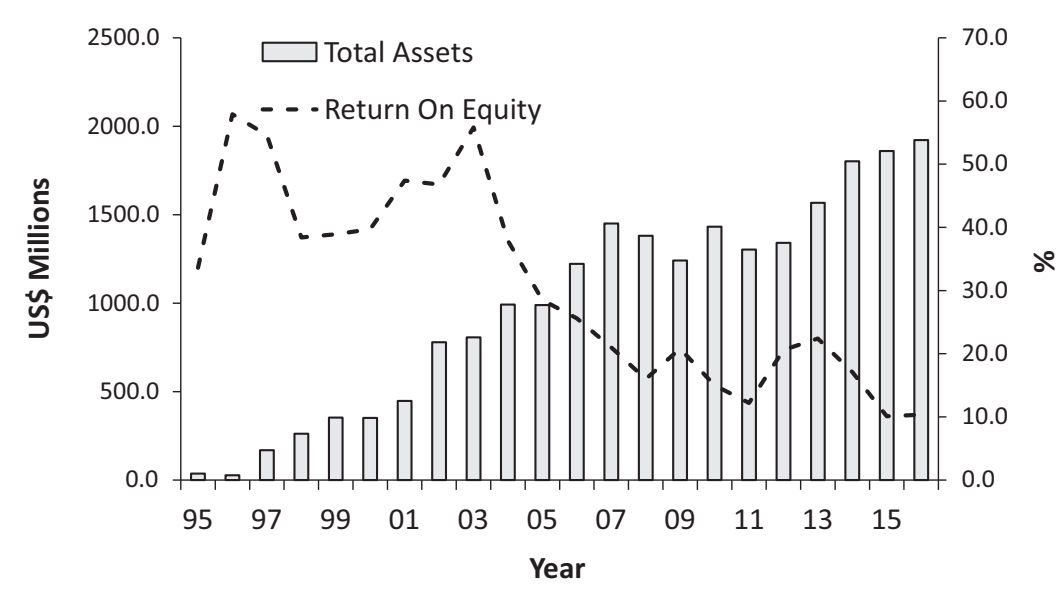




\subsection{MNE productivity and performance}

JMMB leveraged its capacity to forge alliances and securities brokerage know-how as dynamic capabilities for competitive advantage in three Caribbean markets. This was achieved through a business model that provided clients with attractive returns on investments and fast and convenient access to loans (Table 2). The strength of these dynamic capabilities enabled JMMB to quickly align resources with the needs and aspirations of clients (Teece, 2018). The value proposition provided client investors with attractive returns augmented by excellent service quality and convenience.

JMMB extended its business model to foreign markets by committing resources gradually to regional expansion. The strategy involved alliancing with local partners for low risk and small-scale entry, starting at close psychic distance in Trinidad and Barbados and then moved further away to the Dominican Republic in terms of culture. The institution centralized strategic decisions in Jamaica and decentralized operations in each of the three countries. Financing for expansion was obtained mainly by issuing preference share on the Jamaica Stock Exchange.

By 2006, JMMB had become the Caribbean's largest securities brokerage firm with diversified operations in Jamaica, Trinidad and Tobago and the Dominican Republic. JMMB was also a publicly traded company on the stock exchanges of Jamaica, Trinidad and Tobago and Barbados. Total assets increased from US $\$ 0.2$ bn in 1998, before internationalization, to US $\$ 1.9$ bn by 2014 (Table 3). The number of clients grew from just under 40,000 to over 200,000 . However, return on equity (ROE) declined from over $30 \%$ to less than $20 \%$ after the firm entered an international arena where interest rates were lower than those of the home market. Foreign assets as a percentage of total assets increased to $13 \%$ by 2007 when JMMB replicated its securities brokerage business model in Trinidad and the Dominican Republic. By 2014 , foreign assets had risen to $22 \%$ after JMMB transformed its business model to enter the banking segment of the market.

Not surprisingly, growth of total assets coincided with declining ROE because of falling interest rates in Jamaica and even lower rates in Trinidad and the Dominican Republic (Figure 2). Moreover, securities brokerage became a mature product over time, and banking was already at this stage of the life cycle when JMMB entered this market segment. Nonetheless, ROE remained in excess of $10 \%$ which compared favorably with other financial institutions in the Caribbean.

\section{Discussion and conclusions}

The fundamental proposition emerging from this study is that business model must be recognized as a state variable in the Uppsala model of MNE evolution to explain how resources/capabilities give rise to the network position. A business model provides the channel through which the firms resources/capabilities give rise to its network position in respect of productivity and performance. This proposition is important because a theoretical framework must not only provide general guidance but also help to solve specific problems. Financial institutions require special business models due to high governmental regulation of intermediation to promote domestic market efficiency.

This case study adopted the resource-based view of the firm to illustrate the role of a business model as a state variable in the Uppsala model of MNE evolution. The analysis was necessary because the literature on the Uppsala model is unclear about how resources and dynamic capabilities give rise the MNE's network position. This issue is of particular significance for financial firms because of their incremental approach to internationalization (Outreville, 2013). In addition, financial firms that internationalize in small island developing states, such as those of the Caribbean, are severely challenged to achieve economies of scale.

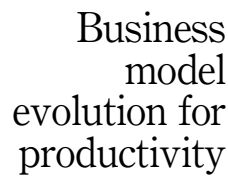


IJPPM

70,2

292

We observed that JMMB's business model was theoretically grounded in the resourcebased view and became the critical mechanism through which resources and dynamic capabilities combine with other elements to establish MNE network position. The business model was a state variable at JMMB and a key unit of analysis for understanding how the firm developed its decision path for internationalization (Teece, 2018; Wirtz et al., 2016). Our conceptual framework situated business model among the other state variables in the Uppsala model. The dynamic capabilities and resources reside on the supply side of the business model. This needs to be complemented by the elements on the demand side including value proposition, customer relationships, customer channels and customer segments.

JMMB created a secondary money market in Jamaica by way of disruptive innovation to provide the most attractive interest rates for small investors using repurchase agreements as the instrument for these transactions. This family business negotiated local joint venture agreements to obtain equity capital to finance its operations. Management also leveraged the secondary money market as a platform to enter the savings and loans market segment by allowing clients to use their investments as collateral. JMMB augmented its core products (securities brokerage and loans) with superior customer service driven by Duncan family values of caring and sharing.

The motivation for regional expansion arose initially from declining spreads on interest rates and later legal restriction in the use of repurchase agreements for investment contracts. JMMB used small-scale entry into foreign markets forming strategic alliances with resident financial institutions to broker money market securities. After acquiring experiential learning, JMMB diversified into formal banking operations and moved gradually from joint ventures to wholly owned subsidiaries. JMMB's internationalization path was nonmonotonic. The institution withdrew from Barbados a few years after entry and shelved plans to penetrate Central America by way of Costa Rica.

The core values of the Duncan family were the critical or Valuable, Rare, Imperfectly Imitable and Nonsubstitutable (VRIN) resource. These not only shaped the business model but also set the criteria and boundaries for business model extension to foreign markets (Pukall and Calabro, 2014; Duh et al., 2010). During the internationalization process, JMMB leveraged its family values to shape organizational culture, physical infrastructure, routine operations and relationships with clients and joint venture partners. Consistent with the Uppsala model, JMMB deployed strategic alliancing, brokerage know-how and risk management as dynamic capabilities to replicate its business model in foreign markets. The firm's entrepreneurial spirit motivated opportunity identification in the domestic and foreign markets.

In respect to theory development, we conclude that the business model played a unique role as a state variable in JMMB's transition to MNE by articulating an explicit value proposition for astute orchestration of resources and dynamic capabilities and creation of the market resonance necessary for generating customer demand (Teece, 2014). This role is crucial for realizing satisfactory MNE productivity and performance. The business model is distinct from the notion of value chain, which refers to the set of direct and indirect activities used to procure resources, produce market and supply goods or services. The resource-based view underscores that the way tangible and intangible assets are leveraged determines whether or not the firm achieves competitive advantage. JMMB's internationalization process illustrates that the business model explicates how the resource-based view is implemented for value creation, delivery and capture.

While our case study illustrates business model as a state variable in the Uppsala model, we are mindful that this study is limited to a single financial firm. These institutions have unique features, such as fungible assets and direct linkage to monetary policy, not present in other organizations. Therefore, the nature of the business model is firm-specific. However, we believe that the role of the business model should be the same. 
Family firms must resolve issues such as member commitment and attitude towards risktaking. Future studies should explore family values for MNE evolution in greater depth. How do families resolve conflicting views about business model decisions? Also, a JMMB Board member posed an interesting question for future research as follows: "Would the business model have worked if JMMB was a non-family owned and managed enterprise?" Altruism and nepotism were evident in the early years and may have stimulated JMMB's productivity and financial performance.

The findings suggest several managerial implications for financial institutions in the Caribbean. Focused service differentiation may be the preferred strategy for maximizing productivity and financial performance in small island developing states. This reduces the need for economies of scale. However, innovation is required to combat product maturation. The stock exchanges in the Caribbean should be leveraged to obtain low cost capital for international expansion. Firms must be prepared to withdraw from foreign markets that become unfavorable and also adjust strategic plans for changing environmental conditions. Finally, core products used to penetrate foreign markets should be augmented with high service quality to deliver the value proposition. Cross-border strategic alliances may be needed to overcome liabilities of newness, foreignness and outsidership. Finally, mergers and acquisitions can help to mitigate lack of experience in foreign markets.

\section{References}

Ahmad, S.Z. (2012), "The internationalization of Malaysian-based multi-national banks. Journey towards globalization”, Asia Pacific Journal of Business, Vol. 4 No. 1, pp. 58-81.

Amaratunga, D. and Baldry, D. (2001), "Case study methodology as a means of theory building: performance measurement in facilities management organisations", Work Study, Vol. 50 No. 3, pp. 95-105, [now International Journal of Productivity and Performance Management].

Augier, M. and Teece, D.J. (2007), "Dynamic capabilities and multinational enterprise: penrosean insights and omissions", Management International Review, Vol. 47 No. 2, pp. 175-192.

Barney, J. (1991), "Firm resources and sustained competitive advantage", Journal of Management, Vol. 17 No. 1, pp. 99-120.

Beck, T., Chen, T., Lin, C. and Song, F.M. (2016), "Financial innovation: the bright and the dark sides", Journal of Banking and Finance, Vol. 72, pp. 25-51.

Bouselama, G. and Herve, L. (2018), "The internationalization of retail banking: the case of French banks", Journal of Management Policy and Practice, Vol. 19 No. 3, pp. 85-105.

Boojihawon, D.K. and Acholono, K.K. (2013), "Internationalisation process of African banks: an exploratory study", African Journal of Economic and Management Studies, Vol. 4. No. 2, pp. 244-266.

Burr, V. (1995), An Introduction to Social Constructionism, Routledge, London.

Caribbean Centre for Money and Finance (2013), Caribbean Economic Performance Report, The University of the West Indies, St. Augustine, Trinidad and Tobago.

Cattani, G. and Tschoegl, A.E. (2002), An Evolutionary View of Internationalization: Chase Manhattan Bank, 1917 to 1996, The Wharton Financial Institutions Center, Philadelphia.

Chesbrough, H. and Rosenbloom, R.S. (2002), "The role of the business model in capturing value from innovation: evidence from xerox corporation's technology spin-off companies", Industrial and Corporate Change, Vol. 11 No. 3, pp. 529-555.

Coviello, N., Kano, L. and Leisch, P.W. (2017), “Adapting the Uppsala model to a modern world: macrocontext and microfoundations", Journal of International Business Studies, Vol. 48 No. 9, pp. 1151-1164.

Creswell, J.W. (2008), Educational Research, 3rd ed., Pearson Education, Upper Saddle River, New Jersey, NJ.

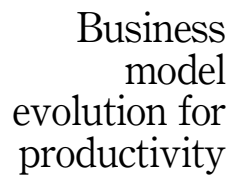

293 
IJPPM

70,2

Cyert, R.M. and March, J.G. (1963), A Behavioral Theory of the Firm, Prentice-Hall, Englewood Cliffs, NJ.

DeYoung, R., Lang, W. and Nolle, B. (2007), "How the internet affects output and performance at community banks", Journal of Finance and Banking, Vol. 31 No. 4, pp. 1033-1060.

Duh, M., Belak, J. and Milfelner, B. (2010), "Core values, culture, and ethical climate as constitutional elements of ethical behaviour: exploring differences between family and non-family enterprises”, Journal of Business Ethics, Vol. 97, pp. 473-489.

Easterby-Smith, M., Thorpe, R. and Jackson, P. (2008), Management Research: Theory and Research, Sage, London, ISBN 9781847871770.

Eisenhardt, K.M. (1989), "Building theories from case study research", Academy of Management Review, Vol. 14 No. 4, pp. 532-550.

Eisenhardt, K.M. and Martin, J.A. (2000), "Dynamic capabilities: what are they?", Strategic Management Journal, Vol. 21, pp. 1105-1121.

Engwall, L. and Hadjikhani, A. (2014), "Internationalization of financial services in turbulent Markets", International Business Review, Vol. 23 No. 6, pp. 1035-1039.

Eppink, D.J. and Van Rhijn, B.M. (1988), "The internationalization of Dutch insurance companies", Long Range Planning”, Vol. 21 No. 5, pp. 54-60.

Forsgren, M. (2016), "A note on the revisited Uppsala internationalization process model-the implications of business networks and entrepreneurship", Journal of International Business Studies, Vol. 47 No. 9, pp. 1135-1144.

Forsgren, M. and Hagstrom, P. (2007), "Ignorant and impatient internationalization? The Uppsala model and internationalization patterns for internet-related firms", Critical Perspectives on International Business, Vol. 3 No. 4, pp. 291-305.

Gerring, J. (2004), "What is a case study and what is it good for?", American Political Science Review, Vol. 98 No. 2, pp. 341-354.

Gibbert, M., Ruigrok, W. and Wicki, B. (2008), "What passes as a rigorous case study?", Strategic Management Journal, Vol. 29 No. 13, pp. 1465-1474.

Grant, R.M. (1991), The Resource-Based Theory of Competitive Advantage: Implications for Strategy Formulation, California Management Review, Spring, pp. 114-135.

Grant, R.M. and Venzin, M. (2009), "Strategic and organisational challenges of internationalization in financial services", Long Range Planning, Vol. 42, pp. 561-587.

He, X. and Wei, Y. (2011), "Linking market orientation to international market selection and international market performance", International Business Review, Vol. 20, pp. 535-546.

Helfat, C.E. and Peteraf, M.A. (2003), "The dynamic resource-based view : capability lifecycles", Strategic Management Journal, Vol. 24, pp. 997-1010.

Helfat, C.E. and Peteraf, M.A. (2015), "Managerial cognitive capabilities and the micro foundations of dynamic capabilities", Strategic Management Journal, Vol. 36 No. 6, pp. 831-850.

Hellman, P. (1996), "The internationalization of Finnish financial service companies", International Business Review, Vol. 5 No. 2, pp. 191-208.

Hindley, B. (2001), Internationalisation of Financial Services: A Trade Policy Perspective, available at: https://www.iatp.org/files/Internationalisation_of_Financial_Services_A_T.htm (accessed 12 November 2018).

Holden, P. and Howell, H. (2009), Enhancing Access to Finance in the Caribbean, Private Sector Development Discussion Paper \#4, Inter-American Development Bank, Washington, DC, USA, October.

International Monetary Fund (2013), Caribbean Small States: Challenges of High Debt and Low Growth, Prepared by the Western Hemisphere Department, Washington, DC, USA, February 20.

Isaac, S. and Michael, W.M. (1990), Handbook in Research and Evaluation. Economic Studies, Edits Publishers, San Diego, California, CA. 
Isaksson, R., Garvare, R. and Johnson, M. (2015), "The crippled bottom line - measuring and managing sustainability", International Journal of Productivity and Performance Management, Vol. 64 No. 3, pp. 334-355.

Johanson, J. and Vahlne, J. (2009), "The Uppsala internationalization process model revisited: from liability of foreignness to liability of outsidership", Journal of International Business Studies, Vol. 40 No. 9, pp. 1411-1431.

Johanson, J. and Vahlne, J. (1977), "The internationalization process of the firm: a model of knowledge development and increasing foreign market commitments", Journal of International Business Studies, Vol. 8 No. 1, pp. 23-32.

Johnson, M.W., Christensen, C.M. and Kagermann, H. (2008), Reinventing Your Business Model, Harvard Business Review, pp. 59-68.

Langley, A. (1999), "Strategies for theorizing from process data", Academy of Management Review, Vol. 24 No. 4, pp. 691-710.

Lee, J.W., Song, H.S. and Kwak, J. (2014), "Internationalization of Korean banks during crises: the network view of learning and commitment", International Business Review, Vol. 23 No. 6, pp. 1040-1048.

Levine, R. (2018), "Finance, growth and economic prosperity", Macroeconomic Review, pp. 82-88.

Marshall, C. and Rossman, G.B. (2014), Designing Qualitative Research, Sage Publications, Thousand Oaks, California, CA.

Ogawa, S., Park, J., Singh, D. and Thacker, N. (2013), Financial Interconnectedness and Financial Sector Reforms in the Caribbean, IMF Working Paper, International Monetary Fund, Western Hemisphere Department, Washington DC, USA. WP/13/175, July.

Osterwalder, A. and Pigneur, Y. (2010), Business Model Generation: A Handbook for Visionaries, Game Changers, and Challengers, Wiley, Hoboken, New Jersey, NJ.

Outreville, J.F. (2013), "A commentary on home-region internationalization in financial groups from emerging economies", Multinational Business Review, Vol. 21 No. 2, pp. 195-207.

Oviatt, B.M. and McDougall, P.P. (1994), "Toward a theory of international new Ventures”, Journal of International Business Studies, Vol. 25 No. 1, pp. 45-64.

Parada, P., Alemany, L. and Planellas, M. (2009), "The internationalization of retail banking:Banco Santander's Journey towards globalization”, Long Range Planning, Vol. 42, pp. 654-677.

Penrose, E.T. (1959), The Theory of the Growth of the Firm, Basil Blackwell, Oxford.

Peteraf, M.A. (1993), "The cornerstones of competitive advantage: a resource-based view”, Strategic Management Journal, Vol. 14, pp. 179-191.

Pukall, T.J. and Calabrò, A. (2014), "The internationalization of family firms: a critical review and integrative model", Family Business Review, Vol. 27 No. 2, pp. 103-125.

Rask, M. (2014), "Internationalization through business model innovation: in search of relevant design dimensions and elements", Journal of International Entrepreneurship, Vol. 12, pp. 146-161.

Schueffel, P., Baldegger, R. and Amman, W. (2014), "Behavioral patterns in born-again global firm", Multinational Business Review, Vol. 22 No. 4, pp. 418-441.

Seven, U. and Yetkiner, H. (2016), "Financial intermediation and economic growth", Economic Systems, doi: 10.1016/j.ecosys.2015.09.004.

Stake, R.E. (2006), Multiple Case Study Analysis, The Guilford Press, New York, NY.

Sun, S.L. (2009), "Internationalization strategy of MNEs from emerging economies: the case of Huawei”, Multinational Business Review, Vol. 17 No. 2, pp. 129-155.

Teece, D.J. (2010), "Business models, business strategy and innovation”, Long Range Planning, Vol. 43 No. 2, pp. 172-194.

Teece, D.J. (2014), "A dynamic capabilities-based entrepreneurial theory of the multinational Enterprise”, Journal of International Business Studies, Vol. 45, pp. 8-37.
Business model evolution for productivity 
IJPPM

70,2

Teece, D.J. (2018), "Business models and dynamic capabilities", Long Range Planning, Vol. 51, pp. 40-49.

Tschoegl, A.E. (1987), "International retail banking as a strategy: an assessment", Journal of International Business Studies, Vol. 18, No. 2, pp. 67-88.

Vahlne, J. and Ivarsson, I. (2014), "The globalization of Swedish MNEs: empirical evidence and theoretical explanations", Journal of International Business Studies, Vol. 45, pp. 227-247.

Vahlne, J. and Johanson, J. (2013), "The Uppsala model on evolution of the multinational Business enterprise - from internalization to coordination of networks", International Marketing Review, Vol. 30 No. 3, pp. 189-210.

Vahlne, J. and Johanson, J. (2020), “The Uppsala model: networks and micro-foundations”, Journal of International Business Studies, Vol. 51 pp. 4-10.

Vahlne, J.-E., Ivarsson, I. and Johanson, J. (2011), “The tortuous road to globalization for Volvo's heavy truck business: extending the scope of the Uppsala model", International Business Review, Vol. 20, pp. 1-14.

Wernerfelt, B. (1984), “A resource-based view of the firm”, Strategic Management Journal, Vol. 5 No. 2 , pp. $171-180$.

Winter, S.G. (2003), "Understanding dynamic capabilities", Strategic Management Journal, October, Vol. 24 Special Issue, pp. 991-996.

Wirtz, B.W., Pistoia, A., Ullrich, S. and Gottel, V. (2016), "Business models: origin, development and future research", Long Range Planning, Vol. 49, pp. 36-54.

Yin, R.K. (2009), Case Study Research: Design and Methods, SAGE Publications, London.

Zott, C. and Amit, R. (2013), "The business model: a theoretically anchored robust construct for strategic analysis", Strategic Organization, Vol. 11 No. 4, pp. 403-411.

\title{
Further reading
}

Easterby-Smith, M., Lyles, M.A. and Peteraf, M.A. (2009), "Dynamic capabilities: current debates and future directions", British Journal of Management, Vol. 20 No. 1, pp. S1-S8.

Teece, D.J. (2007), "Explicating dynamic capabilities: the nature and micro foundations of (sustainable) enterprise performance", Strategic Management Journal, Vol. 28 No. 13, pp. 1319-1350.

\begin{abstract}
About the authors
Dr David W. Parker is a senior lecturer in operations management and system analytics. His focus of research is process improvements and change management intervention to achieve productivity improvement. Recently, he was the recipient of the Mona School of Business, Revolving Scholar Programme, undertaking 3 months research in the West Indies. He has published in IJPPM on topics including agency theory in public-private partnerships, change management, team working and agile leadership, effective communication, synthesizing strategic theories, public services and productivity hurdles and risk evaluation. His current research is in measuring sustainable operations. David W. Parker is the corresponding author and can be contacted at: D.Parker@business.uq.edu.au

Dr William W. Lawrence is a senior lecturer and Director of the Professional Services Unit at Mona School of Business and Management at the University of the West Indies in Kingston Jamaica. His research focuses on application of behavioral theory and the resource-based view for improvements in strategic and operations management. He provides consultancy solutions for companies providing financial services and consumer goods.
\end{abstract}

For instructions on how to order reprints of this article, please visit our website:

www.emeraldgrouppublishing.com/licensing/reprints.htm

Or contact us for further details: permissions@emeraldinsight.com 